Review Article

\title{
The Potential of Food Protein-Derived Bioactive Peptides against Chronic Intestinal Inflammation
}

\author{
Wanying Zhu, ${ }^{1}$ Liying Ren, ${ }^{1}$ Li Zhang, ${ }^{1}$ Qinqin Qiao, ${ }^{2}$ Muhammad Zahid Farooq, ${ }^{3}$ \\ and Qingbiao Xu $\mathbb{B D}^{3,4}$ \\ ${ }^{1}$ Shanxian Central Hospital, Heze 274300, China \\ ${ }^{2}$ College of Information Engineering, Fuyang Normal University, Fuyang 236000, China \\ ${ }^{3}$ College of Animal Sciences and Technology, Huazhong Agricultural University, Wuhan 430070, China \\ ${ }^{4}$ State Key Laboratory of Animal Nutrition, Institute of Animal Sciences, Chinese Academy of Agricultural Sciences, \\ Beijing 100193, China
}

Correspondence should be addressed to Qingbiao Xu; qbxu@mail.hzau.edu.cn

Received 23 June 2020; Accepted 25 August 2020; Published 9 September 2020

Academic Editor: Hongmei Jiang

Copyright (c) 2020 Wanying Zhu et al. This is an open access article distributed under the Creative Commons Attribution License, which permits unrestricted use, distribution, and reproduction in any medium, provided the original work is properly cited.

Inflammation can cause various chronic diseases like inflammatory bowel diseases. Various food protein-derived bioactive peptides (BAPs) with anti-inflammatory activity have the potential to manage these diseases. The aim of this paper is to overview the mechanisms and the molecular targets of BAPs to exert anti-inflammatory activity. In this review, the in vitro and in vivo effects of BAPs on intestinal inflammation are highlighted. The mechanism, pathways, and future perspectives of BAPs as the potential sources of therapeutic treatments to alleviate intestinal inflammation are provided, including nuclear factor- $\kappa \mathrm{B}$, mitogenactivated protein kinase, Janus kinase-signal transducer and activator of transcription, and peptide transporter 1 (PepT1), finding that PepT1 and gut microbiota are the promising targets for BAPs to alleviate the intestinal inflammation. This review provides a comprehensive understanding of the role of dietary BAPs in attenuating inflammation and gives a novel direction in nutraceuticals for people or animals with intestinal inflammation.

\section{Introduction}

Inflammation is a normal immune defense that is generated from the immune system responding to pathogen and infection. Inflammation can cause various chronic diseases, such as inflammatory bowel diseases (IBD), asthma, cancer, cardiovascular diseases, obesity, and diabetes [1]. The intestinal mucosa can be damaged by IBD with chronic inflammatory disorders, including ulcerative colitis (UC) and Crohn's disease (CD). UC is an inflammation of the colon mucosa and submucosa continuity affecting the rectal area, while $\mathrm{CD}$ is a full-thickness inflammation discontinuity affecting the terminal ileum and colon or anus [2]. Until now, the aetiology of intestinal inflammation and IBD remains unclear.

In the intestines of human and animals, dietary proteins are digested into free amino acids and peptides by enzymatic hydrolysis. Some peptides consisting of 2-20 AAs with bio- logical function are named bioactive peptides (BAPs), such as anti-inflammation, antihypertension, antioxidation, antidiabetics, anticancer, antimicrobics, antiadhesion, dipeptidyl peptidase IV inhibition, opioid, and immunomodulation [3]. Conventional drug treatments have adverse side effects, such as potential toxicity and immunogenicity [4]. In recent years, BAPs have attracted more and more attention to treat chronic inflammation diseases as a result of their safety $[1,5]$.

However, limited information of the anti-inflammatory mechanisms of the action of these BAPs is available. In this review, food protein-derived BAPs against intestinal inflammation in vitro and in vivo are discussed. Their molecular targets and the action pathways are overviewed and highlighted. Understanding of the anti-inflammatory actions of BAPs can facilitate further research on managing chronic intestinal inflammation and diseases. Therefore, the purpose of this paper is to highlight the roles of BAPs in anti- 
inflammatory activity and provide future perspectives for the application of BAPs as potential sources of therapeutic management of chronic intestinal diseases.

\section{Intestinal Inflammation}

Inflammation can activate protective proinflammatory mediators, such as interleukin- (IL-) 1, IL-6, IL-8, IL-12, interferon- $\gamma$ (INF- $\gamma)$, and tumor necrosis factor- $\alpha$ (TNF- $\alpha$ ) in immune responses, which include $\mathrm{T}$ and $\mathrm{B}$ lymphocytes. The activated B lymphocytes can produce antibodies, such as IgA, IgG, IgM, and IgE. The T lymphocyte cells consist of $\mathrm{CD}^{+}$and $\mathrm{CD}^{+} \mathrm{T}$ cells. $\mathrm{CD} 4^{+} \mathrm{T}$ cells, named helper $\mathrm{T}$ lymphocytes (Th), have immune regulatory function by secreting cytokines, being classified into Th1 and Th2. Th1 can release IL- 2, IFN- $\gamma$, and TNF- $\alpha$ to promote cellular immunological response, whereas Th2 can release IL-4 and IL-10 to improve immunoresponse, while $\mathrm{CD}^{+} \mathrm{T}$ cells have the function to kill the target cells [6].

Progression of inflammation has four steps: inducers, pathways, mediators, and inflammatory response [7]. The inducers (LPS, dextran sodium sulfate (DSS), 2,4,6-trinitrobenzene sulfonic acid (TNBS), or toxicant) stimulate the sensors that can activate pathways, including nuclear factor- $\kappa \mathrm{B}$ $(\mathrm{NF}-\kappa \mathrm{B})$ and mitogen-activated protein kinase (MAPK). Then, inflammatory mediators (IL-8, TNF- $\alpha$, monocyte chemoattractant protein-1 (MCP-1), or reactive oxygen species (ROS)) are released, leading to the inflammatory response [7]. Proinflammatory cytokines produced mainly by macrophages and mast cells lead to inflammation, while anti-inflammatory cytokines, such as IL-4, IL-10, and transforming growth factor $\beta$ (TGF- $\beta$ ), reduce the production of procytokines in macrophage cells as agonists of toll-like receptor [7]. In in vivo studies, TNBS and DSS are commonly used to induce intestinal inflammation in animal models, causing immune alterations, gut physiology and morphology changes, and colitis symptoms [8]. Moreover, administration of DSS can lead to higher intraluminal IgG [9]. In UC patients, IgG production is dramatically high in the gut; therefore, IgG is an index to grade IBD. Thus, these cytokines with pathology may be the targets for BAPs to prevent chronic inflammation. In addition, it is also known that oxidative stress is associated with chronic intestinal inflammation, and it can decrease antioxidant defenses in the colonic mucosa. Additionally, ROS are released from immune cells and can be overwhelmed by oxidative stress. Therefore, antioxidative BAPs are the candidates for antioxidant defense in inflammatory gut [10], such as IRW [11], IQW [12], EAMAPK, and AVPYPQ [13]. Soybean-derived lunasin can also enhance antioxidant defenses and inhibit inflammation $[14,15]$.

\section{Anti-Inflammatory Peptides Derived from Food Proteins}

In the gut of human or animals, the BAPs encrypted in parent proteins can be released by various enzymatic digestion. However, there are several classical steps toward the in vitro production of novel BAPs from various food protein sources: enzymatic hydrolysis, purification by high-performance liquid chromatography, selection of most promising fraction, peptide sequencing, and final in vitro or in vivo bioactivity test (Figure 1) $[5,7,16]$. Due to their safety, the antiinflammation potential of food-derived BAPs has become an active research area, and the intestinal tract is a main target of BAPs.

Recent knowledge of anti-inflammatory BAPs in in vitro studies with a concentration of $20-1000 \mu \mathrm{M}$ was evaluated using mammalian cells induced by TNF- $\alpha$, LPS, or $\mathrm{H}_{2} \mathrm{O}_{2}$, such as murine RAW 264.7 macrophages and human intestinal epithelial cell line Caco-2 cells (Table 1). There are many food-derived BAPs that can inhibit inflammation via the MAPK or NF- $\kappa$ B pathway (Table 1 ), such as CR, FL, HC, LL, MK [17], DEDTQAMPFR, DEDTQAMPF [18], DYKKY [19], EAMAPK, AVPYPQ [13], FLV [20], GPETAFLR [21], GPR [22], IPAV [23], IRW [24], IQW [12], LDAVNR, MMLDF [25], MLGATSL, MSYSAGF [18], PAY [26], PRRTRMMNGGR, MGPAMMRTMPG [27], QCQQAVQSAV [28], QQQQQGGSQSQ, QEPQESQQ, QQQQQGGSQSQSQKG, PETMQQQQQQ [29], SSEDIKE [30], VPP [31], IPP [32], VPY [33], VH, LAN, IA, AL [34], $\beta$-Ala-His [35], and pyroGlu-Leu [36]. Egg ovotransferrin-derived tripeptide IRW exhibits the antiinflammatory effect through the NF- $\kappa \mathrm{B}$ pathway by inhibiting p65 and p50 [24]. Moreover, whey protein-derived tetrapeptide IPAV can reduce IL- 8 production via the NF- $\kappa$ B and MAPK pathways [23]. While BAPs have shown potential as anti-inflammatory agents in cultured cells, further in vivo studies and underlying mechanism are still necessary to verify their effectiveness in managing chronic inflammation [2].

\section{Pathways Involved in the Inhibition of Chronic Intestinal Inflammation by BAPs}

There are four possible mechanism pathways for BAPs to attenuate chronic intestinal inflammation: NF- $\kappa \mathrm{B}, \mathrm{MAPK}$, Janus kinase-signal transducer and activator of transcription (JAK-STAT), and peptide transporter 1 (PepT1) (Figure 2) [2, 7, 10, 20, 37-41]. Through inhibiting these pathways, BAPs can act the anti-inflammatory function in intestinal cells.

Among these pathways, the NF- $\kappa \mathrm{B}$ and MAPK pathways are two main pathways for BAPs to inhibit inflammation [7]. The NF- $\kappa \mathrm{B}$ is a key regulator of the expression and secretion of inflammatory cytokines (TNF- $\alpha$, IL- $1 \beta$, IL-6, and IL-8) and also plays a vital role in the expressions of cyclooxygenase-2 (COX-2) and inducible nitric oxide synthase (iNOS) [42]. Inflammatory stimuli (IL-1 $\beta$, LPS, TNF$\alpha$, viruses, or oxidative stress) activate inhibitory $\kappa \mathrm{B}$ kinases (IKK $\alpha, \operatorname{IKK} \beta$, and IKK $\gamma$ ), leading to phosphorylation of a potential cytoplasmic transcription factor that contains an inhibitor of $\kappa \mathrm{B}(\mathrm{I} \kappa \mathrm{B} \alpha, \mathrm{I} \kappa \mathrm{B} \beta$, and $\mathrm{I} \kappa \mathrm{B} \gamma)$ and $\mathrm{I} \kappa \mathrm{B} \alpha$ degradation [42]. NF- $\kappa \mathrm{B}$ is a family of transcription factor proteins, including five subunits: p65 (RelA), p50, p52, Rel, and RelB. After dimer p65/p50 is released into the cytosol, it can be translocated into the nucleus and initiates target gene transcription for proinflammatory factors, causing inflammation (Figure 2) [2, 42]. Many food-derived BAPs can inhibit 


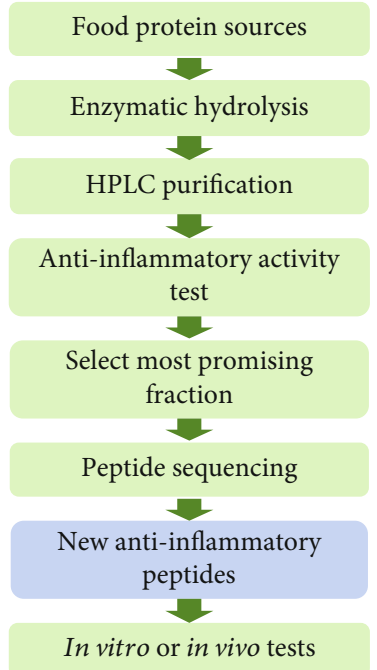

Figure 1: Classical steps toward the production and purification of anti-inflammatory peptides from food protein sources. HPLC: highperformance liquid chromatography. This figure was adapted from previous reports $[3,48,81]$.

inflammation via this NF- $\kappa$ B pathway, such as DYKKY [19], GPR [22], IRW [24], IQW [12], MLGATSL, MSYSAGF [18], pyroGlu-Leu [36], and TMKLLLVTL [43].

Another major signaling pathway, MAPK, can regulate many cellular activities, including proliferation, differentiation, death, and immune response. The stimulus and MAP3K phosphorylation can mediate the phosphorylation of the downstream MAP2K and MAPK, which contain three subfamilies: p38, extracellular signal-regulated kinases (ERK1 and ERK2), and c-Jun N-terminal kinase (JNK). In unstimulated cells, JNK mainly exists in the cytoplasm, but there is also some distribution in the nucleus. After being stimulated, JNK accumulates in the nucleus and causes the corresponding gene (IL-1 and TNF- $\alpha$ ) expression, resulting in inflammatory response (Figure 2) [44]. Various food protein-derived BAPs can inhibit inflammation via this MAPK pathway, such as DEDTQAMPFR, DEDTQAMPF [18], FLV [20], MLGATSL, MSYSAGF [18], $\beta$-Ala-His [35], pyroGlu-Leu [36], DIKTNKPVIF [45], VPP [46], WH [41], $\gamma$-EC, and $\gamma$-EV [47].

Along with the above two pathways, the JAK-STAT pathway is also important for inflammatory response and can regulate hematopoietic cell development and inflammatory cytokines. Phosphorylation of JAK and STATs can form the dimer translocated to the nucleus [38]. BAPs can attenuate inflammation by inhibiting phosphorylation of JAK and STATs. However, the role of this pathway needs further verification for the anti-inflammation of BAPs. The translocations and activation of the substrate proteins from the above three pathways, including transcription factors in the nucleus (AP-1, ATF-2, EIK1, and c-Jun), cause the change of target genes, reducing the productions of proinflammatory cytokines, including IL-1 $\beta$, IL-2, IL-5, IL-8, IL-12, IL-13, IL17 , TNF- $\alpha$, MCP-1, and IFN- $\gamma$. The overexpression of these proinflammatory mediators and the downexpression of anti-inflammatory cytokines (IL-4, IL-10, and TGF- $\beta$ ) can lead to intestinal inflammation. Through regulating these pathways and cytokines, BAPs can attenuate chronic intestinal inflammation and diseases.

\section{Mechanism of Food-Derived Anti- Inflammatory Peptides to Exert Bioactivities}

The potential anti-inflammatory mechanisms of BAPs derived from food proteins through regulating various cytokines or systems are shown in Figure $3[7,48]$. The secretions and expressions of proinflammatory cytokines IL- $1 \beta$, IL-2, IL-5, IL-6, IL-8, IL-12, IL-17, TNF- $\alpha$, and IFN- $\gamma$ can be inhibited by BAPs, as well as the activations of NF- $\kappa \mathrm{B}$ and MAPK pathways, COX-2, ROS, iNOS, and nitric oxide (NO). ROS are associated with inflammatory diseases, and $\mathrm{NO}$ is synthesized by NO synthase (NOS) enzyme (iNOS), and the inhibition of iNOS and ROS activities can suppress NO production. BAPs can also inhibit the expression and release of a transcription factor that drives treg phenotypic differentiation (Foxp3) and T-helper-cell-associated cytokines (Th1, Th2, and Th17) and the secretions of IgG, IgE, and IgA. On the other side, secretions and expressions of anti-inflammatory cytokines (IL-4, IL-10, and TGF- $\beta$ ), $\mathrm{CD} 4^{+} / \mathrm{CD}^{+}$, numbers of macrophages, and superoxide dismutase (SOD) activity can be increased by BAPs. In addition, the gut microbiome, which is an active topic in health, can be normalized by BAPs $[7,48]$. In conclusion, these cytokines and pathways are the molecular targets and mechanisms for BAPs to regulate the intestinal inflammation of human and animals.

Milk-derived VPP and IPP can exhibit beneficial effect in an animal colitis model through anti-inflammatory action for these targets [49]. VPP also reduced TNF- $\alpha$ and IL- $1 \beta$ expression and macrophage accumulation and activation, inhibited adipose inflammation in mice via angiotensinconverting enzyme-dependent cascade [31], and moderated monocyte adhesion to inflamed endothelia via the MAPKJNK pathway [50]. In addition, tripeptides IRW and IQW downregulated the expression of inflammatory proteins via the NF- $\kappa$ B pathway $[12,24]$. Generally, these BAPs can inhibit the expression of cytokines and mediate the NF- $\kappa \mathrm{B}$ and MAPK pathways [1].

\section{The In Vivo Studies of BAPs on Inflammation}

For the in vivo studies of BAPs, various inflammatory models have been used, typically colitis in mice induced by DSS and TNBS. As observed in human CD, the administration of TNBS to mice can release proinflammatory cytokines, followed by infiltration of $\mathrm{T}$ cell $\mathrm{CD} 4^{+}$phenotype. In these studies, the mice with colitis were orally administered with BAPs mostly with an amount of $50-500 \mathrm{mg} / \mathrm{kg}$ body weight/day for several days to weeks (Table 2). Then, the tissues are collected for common evaluation of anti-inflammation of BAPs using morphological, immunological, and biochemical assays [51], such as body weight, colonic length, disease activity index (DAI), lymphocyte proliferation, $\mathrm{CD}^{+} / \mathrm{CD}^{+}$determination, secretory-immunoglobulin-A 


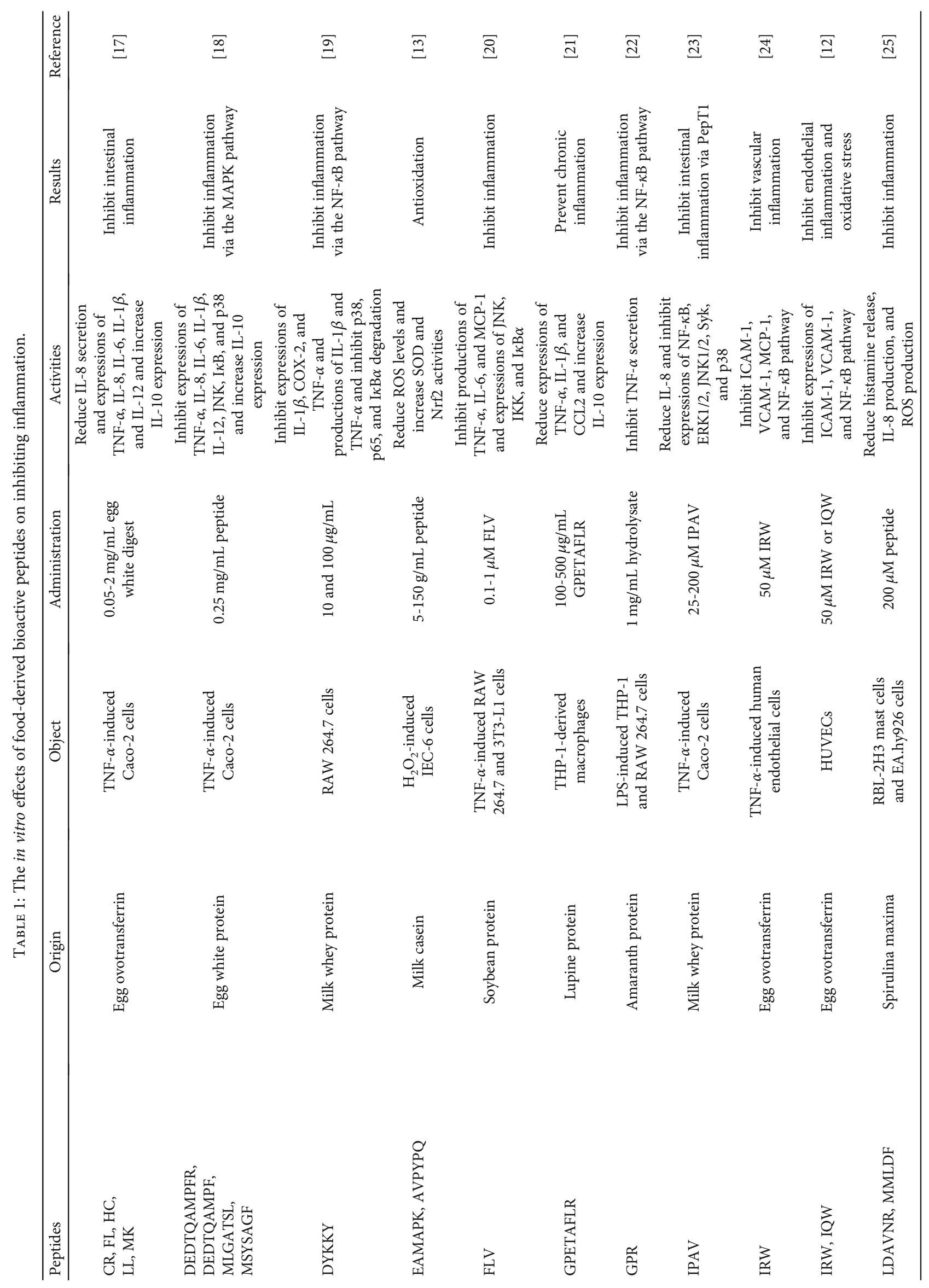




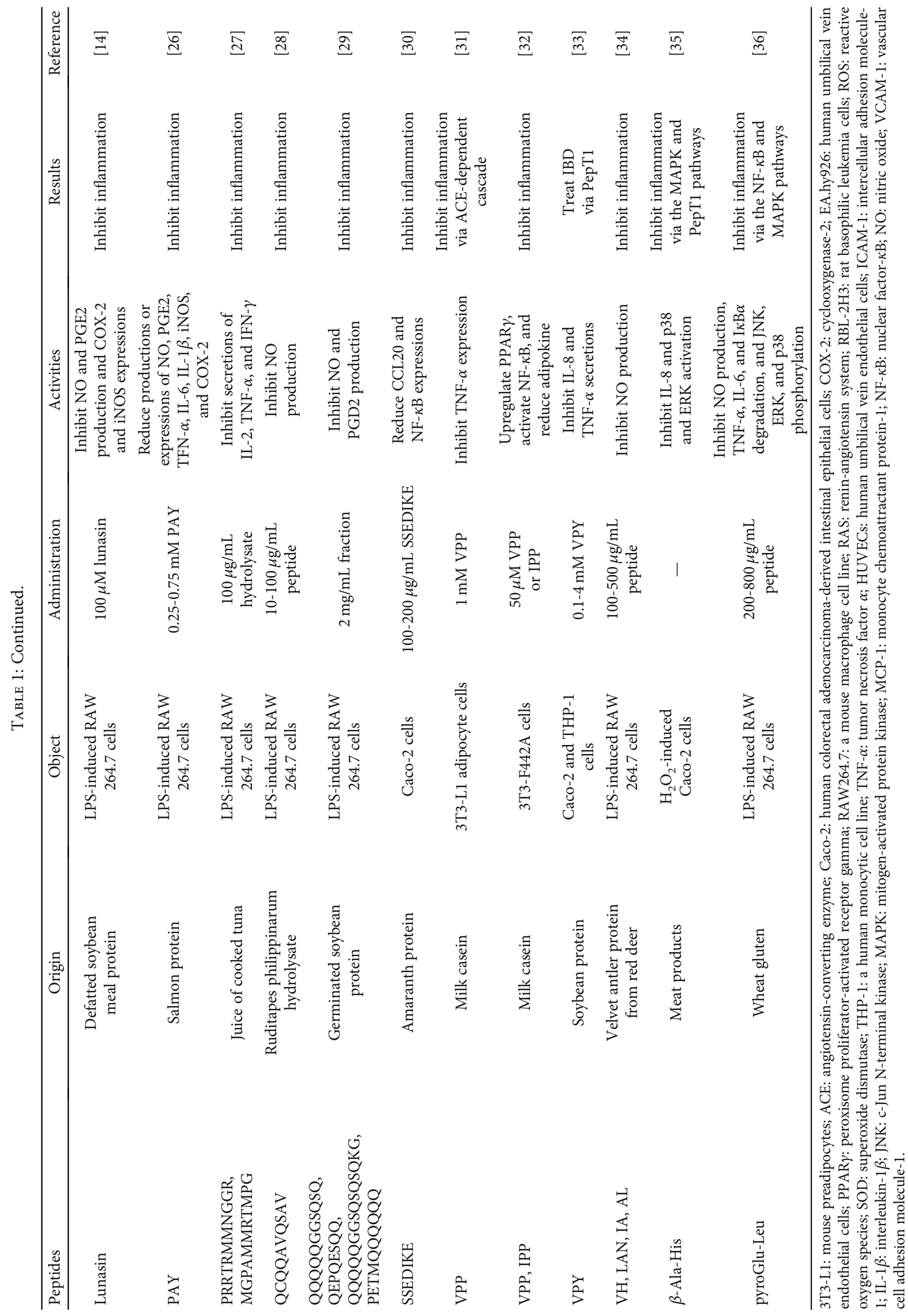




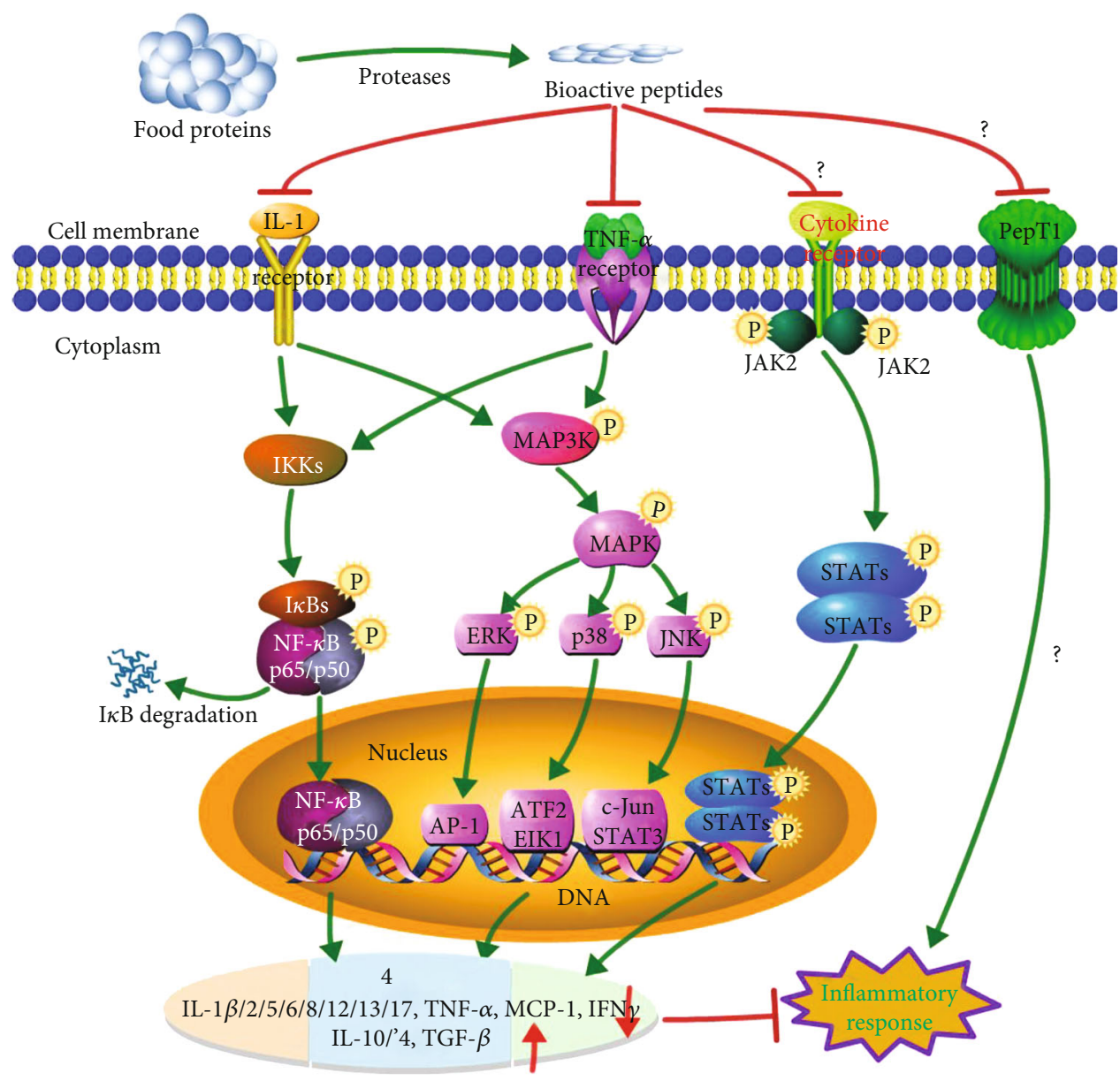

FIGURE 2: Schematic diagram of possible anti-inflammatory mechanism of bioactive peptides derived from food proteins. The antiinflammatory activity may be via the following four pathways: NF- $\kappa$ B, MAPK, JAK-STAT, and PepT1. IL-1: interleukin-1; LPS: lipopolysaccharides; MAPK: mitogen-activated protein kinase; MAP3K: MAPK kinase kinase; NF- $\kappa \mathrm{B}$ : nuclear factor-kappa B; TGF- $\beta$ : transforming growth factor $\beta$; TNF- $\alpha$ : tumor necrosis factor $\alpha$; JAK-STAT: Janus kinase-signal transducer and activator of transcription. This diagram was drawn using an online pathway builder tool (http://www.proteinlounge.com). Adapted from previous reports [2, 7, 10, 20, 37-41].

(s-IgA) measurement, immunoglobulin (IgA, IgM, and IgG) determination, and cytokine (IL-1, IL-2, IL-6, IL-8, IL-10, TNF- $\alpha$, and IFN- $\gamma$ ) measurements (Table 2).

Numbers of BAPs derived from various food proteins (milk, plant, egg, soybean, meat, wheat, rice, potato, corn silk, fish, etc.) have been found to be well suited to treat inflammation or IBD symptoms in vivo (Table 2), such as Ala-Gln (AQ) [9, 52-54], DIKTNKPVIF [45], EWP [55], GLTSK [56], glycomacropeptide [57-60], lunasin [15], IRW [11, 61-63], IQW [62-64], KGHYAERVG [65], KPV [66], PTGADY [67], QCQCAVEGGL [68], QEPVL, QEPV [6], RILSILRHQNLLKELQDLAL [69], SSEDIKE [70], TMKLLLVTL [43], VPP [31, 46, 71, 72], IPP [71, 72], VPY [33], WH [41], casein hydrolysates [73], soybean dipeptides and tripeptides [74], peptide P-317 [75], pyroGlu-Leu [76], $\beta$-Casofensin [77], $\gamma$-EC, and $\gamma$-EV [47]. These studies suggest that oral administration of food-derived BAPs have anti-inflammatory effects, and they can be the therapeutic agents for inflammatory-related diseases, including IBD [78].

Oral administration of dipeptide AQ reduced inflammatory cytokine expression, enhancing the mucosa recovery in
DSS-induced mice [53]. Likewise, intravenous infusion with AQ to calves with early weaned stress can increase concentrations of $\operatorname{IgA}, \mathrm{IgG}, \mathrm{s}-\mathrm{IgA}, \mathrm{CD} 2^{+}$and $\mathrm{CD} 4^{+}$lymphocytes, and $\mathrm{CD}^{+} / \mathrm{CD}^{+}$ratio; therefore, the diarrhea occurrence was decreased [52]. Bean protein is also a rich resource for BAPs. For example, bean- and yeast extract-derived flavor peptide $\gamma$-EC and $\gamma$-EV can inhibit the inflammation in IBD mice [47]. Soybean-derived dipeptides and tripeptides decreased the colonic expressions of proinflammatory IFNG, IL-1B, IL-12B, TNF, and IL-17A and MPO activity and increased Foxp 3 expression and $\mathrm{CD} 4^{+} \mathrm{CD} 25^{+} \mathrm{T}$ cells; therefore, the colon and ileum inflammation of piglets with DSS-induced colitis was attenuated [74]. In addition, with the infusion of $150 \mathrm{mg} / \mathrm{kg}$ of egg white protein-derived EWP, weight loss, crypt distortion, IL- 6 and TNF- $\alpha$ concentrations, and expressions of IL- $1 \beta$, IL- 8 , IL-17, and IFN- $\gamma$ in the colon of piglets with DSS-induced colitis can be reduced, and gut barrier function was restored [55], as well as the barrier protection effects of milk-derived $\beta$-Casofensin [77] and dipeptide AQ [53]. Therefore, food-derived BAPs can contribute to disease treatment through modifying intestinal barrier function [79]. 


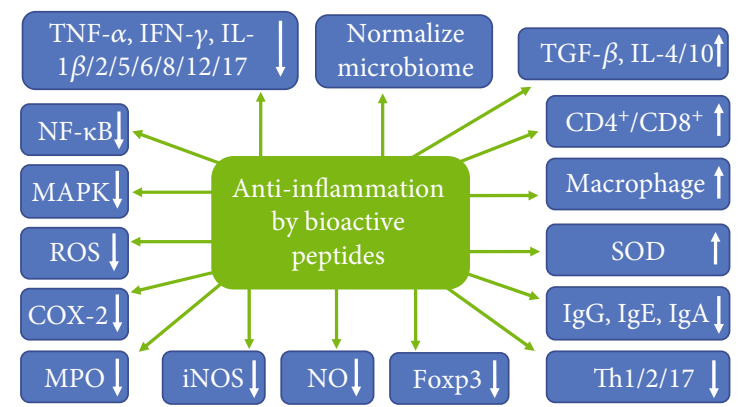

FIGURE 3: The potential mechanisms of anti-inflammatory action of food-derived bioactive peptides. $\mathrm{CD}^{+} / \mathrm{CD}^{+}$: splenic T lymphocyte subpopulations; COX-2: cyclooxygenase-2; Foxp3: a transcription factor that drives treg phenotypic differentiation; iNOS: inducible oxide nitric synthase; IFN- $\gamma$ : interferon- $\gamma$; IL- $1 \beta$ : interleukin- $1 \beta$; MAPK: mitogen-activated protein kinase; MPO: myeloperoxidase; NF- $\kappa$ B: nuclear factor $-\kappa B$; NO: nitric oxide; ROS: reactive oxygen species; SOD: superoxide dismutase; TNF- $\alpha$ : tumor necrosis factor $\alpha$; TGF- $\beta$ : transforming growth factor $\beta$; Th1/2/17: T-helper-cellassociated cytokine $1 / 2 / 17$. This figure was adapted from previous reports $[7,48]$.

In DSS-induced mice, antioxidant enzyme activities and microbial diversity and abundance were increased and the colitis was attenuated by egg white protein-derived IRW and IQW [63]. Oral administration of corn silk extract-derived TMKLLLVTL suppressed IKK $\beta$ activity, I $\kappa \mathrm{B}$ phosphorylation, NF- $\kappa \mathrm{B}$ activity, and IL- $1 \beta$ production in LPS-induced inflammatory mice [43]. Drinking water with soybean-derived tripeptide VPY can reduce DAI, weight loss, MPO activity, and expressions of IL- $1 \beta$, IL- 6 , IL-17, IFN- $\gamma$, and TNF- $\alpha$ in colitis mice [33], suggesting that VPY can treat IBD. In addition, sardine muscle hydrolysate-derived dipeptide $\mathrm{WH}$ can reduce DSS-induced colitis symptoms, colonic cytokine expression, MAPK and $\mathrm{I} \kappa \mathrm{B} \alpha$ activation, and IL- 8 secretion in colitis mice, indicating that $\mathrm{WH}$ can inhibit intestinal inflammation [41]. Favor peptide $\gamma$-EC and $\gamma$-EV inhibited $\mathrm{I} \kappa \mathrm{B} \alpha$ and JNK activation and expressions of IL- $1 \beta$, IL- 6 , IL17, INF- $\gamma$, and TNF- $\alpha$ and increased IL-10 expression in IBD mice [47]. Moreover, tripeptide KPV reduced intestinal inflammation by decreasing IL-1 $\beta$, IL-6, IL-12, and IFN- $\gamma$ expressions and attenuated colitis via PepT1 [66].

Milk protein is a rich source for BAPs, which has potential beneficial effects to the gut of humans and animals [80, 81]. Milk casein-derived VPP and IPP are two famous BAPs with antihypertensive and anti-inflammatory activities. Proinflammatory IL- 6 and IL- $1 \beta$ were reduced, and atherosclerosis was attenuated by oral administration of VPP and IPP [71]. Arterial dysfunction was attenuated by drinking water with VPP and IPP through increasing vasorelaxation and nitrite and nitrate and reducing pulse wave velocity and cardiac and renal damage [72]. It was reported that VPP attenuated inflammation via the MAPK-JNK pathway by reducing monocytes, macrophages, CD18, IL-6, and MCP-1 in adipose inflammatory mice [46]. Milk casein-derived QEPVL and QEPV reduced nitric oxide (NO) release, increased anti-inflammatory IL- 4 and IL-10 production, and decreased productions of IFN- $\gamma$ and TNF- $\alpha$ in LPS- induced mice [6]. Milk $\kappa$-casein-derived glycomacropeptide inhibited inflammation and attenuated colitis via normalizing the inflammatory cytokine and the NF- $\kappa \mathrm{B}$ and MAPK pathways in previous studies [57-60].

From these in vivo studies, the evidences that the intestinal inflammation can be attenuated by oral administration of food protein-derived BAPs have been presented. As many studies have been performed recently, large-scale human and animal trials are still lacking [2]. It has been reviewed that numbers of BAPs can be transported into the bloodstream of humans or animals to exert bioactivities [3, 81]. However, there is still limitation for such in vivo studies due to the possible degradation of BAPs by peptidases in the gut and plasma or insufficient absorption [82]. In the future, more studies of humans and animals are needed to evaluate the anti-inflammatory effects of BAPs, as well as the doses, times, and kinetics in the body.

\section{Peptide Transporter PepT1}

The peptide transporter 1 (PepT1) can transport small peptides from the intestine into the bloodstream of humans or animals [83-85], particularly di- and tripeptides, and its expression in intestinal epithelial cells is increased when the intestine is suffering from inflammation [86], indicating that PepT1 is a gateway to inflammatory response [87]. Similarly, PepT1 can transport various BAPs into intestinal epithelial cells to exert bioactivities $[3,81]$, such as IPAV [23], KPV [66], LKP, IQW [88], LSW [89], IWH, IW [90], and VPY [33].

It was reported that anti-inflammatory tripeptide KPV can attenuate intestinal inflammation associated with PepT1 expression, and KPV lost the anti-inflammatory function without PepT1 expression, suggesting that PepT1 mediates the anti-inflammation of KPV [66]. It was reported that soy protein-derived tripeptide VPY exerted anti-inflammatory activity in cells also through PepT1, which can transport VPY into cells [33]. In addition, pharmacological inhibition of PepT1 can counteract the inhibition of IL- 8 expression mediated by peptide IPAV [23]. Moreover, the antiinflammatory effect of meat-derived carnosine ( $\beta$-Ala-His) was inhibited by dipeptide Gly-Sar, a PepT1 substrate [35]. These findings indicate that PepT1 is a promising target to treat intestinal inflammation by transporting sufficient short-chain BAPs into colonic cells [10]. In conclusion, PepT1 is a possible mechanism for the inhibition of intestinal inflammation by BAPs. However, this PepT1 pathway involved in anti-inflammation of BAPs still needs to be verified by further researches in the future (Figure 2).

\section{Impact of Anti-Inflammatory Peptides on Gut Microbiota}

When intestinal inflammation or IBD occurs, the gut microbial community would also change, such as the decrease of Firmicutes (particularly Clostridium groups) and the increase of Bacteroides, Lactobacillus, Eubacterium, and Proteobacteria [91]. In DSS-induced colitis mice, compositions and varieties of the gut microorganism 
TABLE 2: The in vivo effect of bioactive peptides on inhibiting inflammation.

\begin{tabular}{|c|c|c|c|c|c|c|}
\hline Peptides & Origin & Object & Administration & Activities & Results & Reference \\
\hline AQ & Synthesis & $\begin{array}{l}\text { Early-weaned } \\
\text { calves }\end{array}$ & $\begin{array}{l}\text { Intravenous } \\
\text { infusion } \\
1.01 \mathrm{~g} / \mathrm{kg} \\
\mathrm{BW} / \mathrm{d} \mathrm{AQ}\end{array}$ & $\begin{array}{c}\text { Increase } \\
\text { concentrations of } \\
\mathrm{CD} 2^{+} \text {and } \mathrm{CD} 4^{+} \\
\text {lymphocytes, } \\
\mathrm{CD} 4^{+} / \mathrm{CD}^{+} \text {ratio, } \\
\text { and IgA, IgG, and } \\
\text { s-IgA and improve } \\
\text { intestinal integrity }\end{array}$ & $\begin{array}{c}\text { Improve gain } \\
\text { performance and } \\
\text { decrease diarrhea } \\
\text { occurrence }\end{array}$ & {$[52]$} \\
\hline AQ & Synthesis & $\begin{array}{l}\text { DSS-induced } \\
\text { colitis C57BL/6 } \\
\text { mice }\end{array}$ & $\begin{array}{c}\text { Inject } 75 \mathrm{mg} / \mathrm{kg} \\
\mathrm{BW} / \mathrm{d} \mathrm{AQ}\end{array}$ & $\begin{array}{c}\text { Reduce } \\
\text { Th1/Th2/Th17, } \\
\text { haptoglobin, IgG, } \\
\text { chemokine, and } \\
\text { MPO activity }\end{array}$ & Attenuate colitis & [9] \\
\hline AQ & Synthesis & $\begin{array}{l}\text { DSS-induced } \\
\text { colitis C57BL/6 } \\
\text { mice }\end{array}$ & $\begin{array}{c}\text { Inject } 75 \mathrm{mg} / \mathrm{kg} \\
\mathrm{BW} / \mathrm{d} \mathrm{AQ}\end{array}$ & $\begin{array}{c}\text { Increase colon } \\
\text { length, TLR4, NF- } \kappa \mathrm{B} \\
\text { activation, and } \\
\text { expressions of mucin } \\
2, \mathrm{IL}-17 \text {, and TNF- } \alpha \\
\text { and reduce IgG, DAI, } \\
\text { and haptoglobin }\end{array}$ & $\begin{array}{c}\text { Inhibit } \\
\text { inflammation and } \\
\text { enhance mucosa } \\
\text { recovery }\end{array}$ & {$[53]$} \\
\hline AQ & Synthesis & $\begin{array}{l}\text { DSS-induced } \\
\text { colitis C57BL/6 } \\
\text { mice }\end{array}$ & $\begin{array}{c}\text { Inject } 75 \mathrm{mg} / \mathrm{kg} \\
\mathrm{BW} / \mathrm{d} \mathrm{AQ}\end{array}$ & $\begin{array}{l}\text { Reduce IL-17, Th17, } \\
\text { and macrophage }\end{array}$ & $\begin{array}{c}\text { Inhibit } \\
\text { inflammation }\end{array}$ & {$[54]$} \\
\hline DIKTNKPVIF & $\begin{array}{l}\text { Potato protein } \\
\text { hydrolysate }\end{array}$ & $\begin{array}{l}\text { HFD-fed } \\
\text { SAMP8 mice }\end{array}$ & $\begin{array}{l}\text { Oral and } \\
\text { intraperitoneal } \\
\text { injection }\end{array}$ & $\begin{array}{l}\text { Reduce expressions } \\
\text { of p-p38, FGF-2, } \\
\text { TNF- } \alpha \text {, and IL-6 }\end{array}$ & $\begin{array}{l}\text { Attenuate } \\
\text { proinflammatory } \\
\text { reaction via the } \\
\text { MAPK pathway }\end{array}$ & {$[45]$} \\
\hline EWP & $\begin{array}{l}\text { Egg white } \\
\text { protein }\end{array}$ & $\begin{array}{l}\text { DSS-induced } \\
\text { IBD in piglets }\end{array}$ & $\begin{array}{c}\text { Infuse } \\
150 \mathrm{mg} / \mathrm{kg} \mathrm{BW} \\
\text { EWP for } 5 \text { days }\end{array}$ & $\begin{array}{l}\text { Reduce weight loss, } \\
\text { crypt distortion, and } \\
\text { expressions of TNF- } \\
\alpha \text {, IL-6, IL-1 } \beta \text {, IFN- } \gamma \text {, } \\
\text { IL-8, and IL-17 and } \\
\text { restore gut barrier } \\
\text { function }\end{array}$ & Manage IBD & {$[55]$} \\
\hline GLTSK & $\begin{array}{l}\text { Phaseolus } \\
\text { vulgaris }\end{array}$ & $\begin{array}{l}\text { AOM/DSS- } \\
\text { induced colitis } \\
\text { BALB/c mice }\end{array}$ & $\begin{array}{l}\text { Oral } 50 \mathrm{mg} / \mathrm{kg} \\
\text { BW/d GLTSK }\end{array}$ & $\begin{array}{l}\text { Reduce DAI and } \\
\text { neoplasms and } \\
\text { enhance colon length }\end{array}$ & Attenuate colitis & {$[56]$} \\
\hline Glycomacropeptide & Milk $\kappa$-casein & $\begin{array}{l}\text { TNBS-induced } \\
\text { ileitis rat }\end{array}$ & $\begin{array}{l}\text { Oral } 500 \mathrm{mg} / \mathrm{kg} \\
\text { BW/d peptide }\end{array}$ & $\begin{array}{c}\text { Reduce DAI, MPO, } \\
\text { alkaline phosphatase, } \\
\text { iNOS, IL-1 } \beta, \text { IL-17, } \\
\text { and TNF }\end{array}$ & $\begin{array}{l}\text { Attenuate ileitis via } \\
\text { reducing IL-17 }\end{array}$ & {$[57]$} \\
\hline Glycomacropeptide & Milk $\kappa$-casein & $\begin{array}{l}\text { DSS-induced } \\
\text { colitis C57BL/6 } \\
\text { female mice }\end{array}$ & $\begin{array}{c}\text { Gavage } \\
500 \mathrm{mg} / \mathrm{kg} \\
\text { BW/d peptide }\end{array}$ & $\begin{array}{c}\text { Reduce DAI and } \\
\text { normalize colonic } \\
\text { expressions of IL-1 } \beta \text {, } \\
\text { IL17, IL23, IL6, TGF- } \\
\beta \text {, IL10, and Foxp3 }\end{array}$ & $\begin{array}{c}\text { Inhibit } \\
\text { inflammation }\end{array}$ & [58] \\
\hline Glycomacropeptide & Milk $\kappa$-casein & $\begin{array}{l}\text { DSS-induced } \\
\text { colitis mice }\end{array}$ & $\begin{array}{l}\text { Gavage } \\
15 \mathrm{mg} / \mathrm{d} \\
\text { peptide }\end{array}$ & $\begin{array}{l}\text { Increase BW and } \\
\text { reduce DAI, CD4 } 4^{+} \text {, } \\
\text { IFN- } \gamma \text {, and MPO } \\
\text { activity }\end{array}$ & $\begin{array}{l}\text { Inhibit colitis } \\
\text { inflammation }\end{array}$ & {$[59]$} \\
\hline Glycomacropeptide & Milk $\kappa$-casein & $\begin{array}{l}\text { Oxazolone- } \\
\text { induced } \\
\text { ulcerative colitis } \\
\text { BALB/c mice }\end{array}$ & $\begin{array}{l}\text { Oral } 50 \mathrm{mg} / \mathrm{kg} \\
\text { BW/d peptide }\end{array}$ & $\begin{array}{l}\text { Inhibit NF- } \kappa \mathrm{B} \text { and } \\
\text { MAPK activations } \\
\text { and reduce serum IL- } \\
1 \beta, \text { IL- } 5 \text {, IFN- } \gamma \text {, } \\
\text { TNF- } \alpha \text {, and IL-10 } \\
\text { production }\end{array}$ & Attenuate colitis & {$[60]$} \\
\hline
\end{tabular}


TABle 2: Continued.

\begin{tabular}{|c|c|c|c|c|c|c|}
\hline Peptides & Origin & Object & Administration & Activities & Results & Reference \\
\hline Lunasin & $\begin{array}{l}\text { Soybean } \\
\text { protein }\end{array}$ & $\begin{array}{l}\text { LPS-induced } \\
\text { airway } \\
\text { inflammation } \\
\text { mice }\end{array}$ & $\begin{array}{l}\text { Intranasal } \\
20 \mu \mathrm{g} / \mathrm{mice} \\
\text { lunasin }\end{array}$ & $\begin{array}{l}\text { Reduce infiltration, } \\
\text { goblet cell } \\
\text { metaplasia, and Th2 } \\
\text { cytokine expression }\end{array}$ & $\begin{array}{c}\text { Alleviate } \\
\text { inflammation }\end{array}$ & [15] \\
\hline IRW & $\begin{array}{c}\text { Egg } \\
\text { ovotransferrin }\end{array}$ & $\begin{array}{c}\text { Spontaneously } \\
\text { hypertensive rat }\end{array}$ & $\begin{array}{l}\text { Oral } 15 \mathrm{mg} / \mathrm{kg} \\
\text { BW/d IRW }\end{array}$ & $\begin{array}{l}\text { Reduce ICAM-1 and } \\
\text { VCAM-1 expression }\end{array}$ & $\begin{array}{c}\text { Inhibit } \\
\text { inflammation and } \\
\text { hypertension via the } \\
\text { NF- } \kappa \text { B pathway }\end{array}$ & [11] \\
\hline IRW & $\begin{array}{c}\text { Egg } \\
\text { ovotransferrin }\end{array}$ & $\begin{array}{l}\text { LPS-induced } \\
\text { inflammatory } \\
\text { peritonitis in rat }\end{array}$ & $\begin{array}{l}\text { Oral } 40 \mathrm{mg} / \mathrm{kg} \\
\text { IRW in feed }\end{array}$ & $\begin{array}{l}\text { Reduce serum TNF- } \\
\alpha \text { and IL- } 6 \text { and MPO } \\
\text { activity, increase } \\
\text { Shannon index, and } \\
\text { decrease Simpson } \\
\text { indices }\end{array}$ & $\begin{array}{c}\text { Attenuate } \\
\text { inflammation }\end{array}$ & {$[61]$} \\
\hline IRW, IQW & $\begin{array}{c}\text { Egg } \\
\text { ovotransferrin }\end{array}$ & $\begin{array}{l}\text { DSS-induced } \\
\text { colitis in mice }\end{array}$ & $\begin{array}{c}\text { Drink water } \\
\text { with } 30 \mathrm{mg} / \mathrm{mL} \\
\text { peptide }\end{array}$ & $\begin{array}{l}\text { Increase antioxidant } \\
\text { enzyme activities and } \\
\text { microbial diversity } \\
\text { and abundance }\end{array}$ & Attenuate colitis & [63] \\
\hline IRW, IQW & $\begin{array}{c}\text { Egg } \\
\text { ovotransferrin }\end{array}$ & $\begin{array}{l}\text { DSS-induced } \\
\text { colitis in mice }\end{array}$ & $\begin{array}{c}\text { Oral } 0.03 \% \\
\text { peptide in diet }\end{array}$ & $\begin{array}{l}\text { Reduce TNF- } \alpha \text { and } \\
\text { IL-17 }\end{array}$ & $\begin{array}{l}\text { Inhibit colonic } \\
\text { inflammation }\end{array}$ & [64] \\
\hline IRW, IQW & $\begin{array}{c}\text { Egg } \\
\text { ovotransferrin }\end{array}$ & $\begin{array}{l}\text { Citrobacter } \\
\text { rodentium- } \\
\text { induced colitis } \\
\text { in mice }\end{array}$ & $\begin{array}{c}\text { Oral } 0.03 \% \\
\text { peptide in diet }\end{array}$ & $\begin{array}{l}\text { Regulate intestinal } \\
\text { microorganisms }\end{array}$ & $\begin{array}{l}\text { Inhibit colonic } \\
\text { inflammation }\end{array}$ & {$[62]$} \\
\hline KGHYAERVG & Rice & $\begin{array}{l}\text { Autoimmune } \\
\text { encephalitis } \\
\text { mice }\end{array}$ & $\begin{array}{l}\text { Oral } 100 \mathrm{mg} / \mathrm{kg} \\
\text { peptide }\end{array}$ & $\begin{array}{l}\text { Reduce productions } \\
\text { of IL-17, IFN- } \gamma \text {, IL- } \\
23 \text {, and IL-12 and } \\
\text { increase T cells }\end{array}$ & $\begin{array}{l}\text { Attenuate } \\
\text { autoimmune } \\
\text { encephalitis }\end{array}$ & {$[65]$} \\
\hline KPV & $\begin{array}{l}\text { C-terminal } \\
\text { sequence of } \\
\alpha \text {-melanocyte } \\
\text { stimulating } \\
\text { hormone }\end{array}$ & $\begin{array}{l}\text { DSS- and } \\
\text { TNBS-induced } \\
\text { colitis in mice }\end{array}$ & $\begin{array}{c}\text { Drink water } \\
\text { with } 100 \mu \mathrm{M} \\
\text { KPV }\end{array}$ & $\begin{array}{l}\text { Decrease expressions } \\
\text { of IL-6, IL-12, IFN- } \gamma \text {, } \\
\text { and IL- } 1 \beta\end{array}$ & $\begin{array}{c}\text { Reduce intestinal } \\
\text { inflammation via } \\
\text { PepT1 }\end{array}$ & {$[66]$} \\
\hline PTGADY & $\begin{array}{c}\text { Alaska pollock } \\
\text { hydrolysates }\end{array}$ & $\begin{array}{l}\text { Hydrogenated } \\
\text { cortisone- } \\
\text { treated mice }\end{array}$ & $\begin{array}{c}\text { Oral 50- } \\
200 \mathrm{mg} / \mathrm{kg} \\
\text { BW/d } \\
\text { hydrolysate }\end{array}$ & $\begin{array}{c}\text { Increase productions } \\
\text { of IL-2, IL-4, and } \\
\text { IL-6 }\end{array}$ & Immunomodulation & [67] \\
\hline QCQCAVEGGL & $\begin{array}{l}\text { Crassostrea } \\
\text { gigas }\end{array}$ & $\begin{array}{l}\text { DSS-induced } \\
\text { colitis mice }\end{array}$ & $\begin{array}{c}\text { Oral } 50 \mathrm{mg} / \mathrm{kg} \\
\text { BW/d } \\
\text { hydrolysate }\end{array}$ & $\begin{array}{l}\text { Reduce IgE and } \\
\text { increase spleen } \\
\mathrm{CD} 4^{+} / \mathrm{CD} 8^{+}\end{array}$ & Attenuate colitis & {$[68]$} \\
\hline QEPVL, QEPV & Milk casein & $\begin{array}{l}\text { LPS-induced } \\
\text { mice }\end{array}$ & $\begin{array}{l}\text { Oral } 200 \mathrm{mg} / \mathrm{kg} \\
\mathrm{BW} / \mathrm{d} \text { peptide }\end{array}$ & $\begin{array}{l}\text { Reduce NO release, } \\
\text { increase IL- } 4 \text { and } \\
\text { IL- } 10 \text { production, } \\
\text { and decrease IFN- } \gamma \\
\text { and TNF- } \alpha \\
\text { production }\end{array}$ & $\begin{array}{c}\text { Inhibit } \\
\text { inflammation }\end{array}$ & {$[6]$} \\
\hline RILSILRHQNLLKELQDLAL & $\begin{array}{c}\text { Chromogranin } \\
\text { A }\end{array}$ & $\begin{array}{l}\text { DSS-induced } \\
\text { colitis in mice }\end{array}$ & $\begin{array}{l}\text { Intracolonic } \\
\text { injection } \\
2.5 \mathrm{mg} / \mathrm{kg} / \mathrm{day} \\
\text { peptide }\end{array}$ & $\begin{array}{l}\text { Reduce IL-18, active } \\
\text { macrophages, } \\
\text { increase TJ proteins }\end{array}$ & Attenuate colitis & {$[69]$} \\
\hline SSEDIKE & $\begin{array}{l}\text { Amaranth } \\
\text { seeds }\end{array}$ & $\begin{array}{l}\text { IgE-mediated } \\
\text { food allergy } \\
\text { mouse }\end{array}$ & $\begin{array}{l}\text { Gavage } 100 \mu \mathrm{g} \\
\text { SSEDIKE }\end{array}$ & $\begin{array}{l}\text { Reduce productions } \\
\text { of IgE, IgG, IL-5, IL- } \\
13 \text {, and NF- } \kappa \text { B and } \\
\text { increase TGF- } \beta \text { and } \\
\text { Foxp3 expressions }\end{array}$ & $\begin{array}{l}\text { Inhibit intestinal } \\
\text { inflammation }\end{array}$ & {$[70]$} \\
\hline
\end{tabular}


TABle 2: Continued.

\begin{tabular}{|c|c|c|c|c|c|c|}
\hline Peptides & Origin & Object & Administration & Activities & Results & Reference \\
\hline TMKLLLVTL & $\begin{array}{c}\text { Corn silk } \\
\text { extract }\end{array}$ & $\begin{array}{l}\text { LPS-induced } \\
\text { inflammatory } \\
\text { mice }\end{array}$ & $\begin{array}{l}\text { Oral } 1 \mathrm{mg} / \mathrm{kg} \\
\text { peptide }\end{array}$ & $\begin{array}{c}\text { Inhibit IL- } \beta \text {, } \\
\text { IKK } \beta \text {, and I } \kappa \mathrm{B} \\
\text { phosphorylation and } \\
\text { NF- } \kappa \mathrm{B} \text { activation }\end{array}$ & $\begin{array}{c}\text { Inhibit } \\
\text { inflammation via } \\
\text { the IKK } \beta \text {-NF- } \kappa \mathrm{B} \\
\text { pathways }\end{array}$ & [43] \\
\hline VPP & Milk casein & $\begin{array}{l}\text { HFD-induced } \\
\text { adipose } \\
\text { inflammation } \\
\text { mice }\end{array}$ & $\begin{array}{l}\text { Drink water } \\
\text { with } 0.3 \mathrm{mg} / \mathrm{mL} \\
\text { VPP for } 10 \\
\text { weeks }\end{array}$ & $\begin{array}{l}\text { Reduce monocytes, } \\
\text { macrophages, CD18, } \\
\text { IL-6, and MCP-1 }\end{array}$ & $\begin{array}{c}\text { Attenuate } \\
\text { inflammation via } \\
\text { the MAPK-JNK } \\
\text { pathway }\end{array}$ & [46] \\
\hline VPP & Milk casein & $\begin{array}{l}\text { Obesity- } \\
\text { induced adipose } \\
\text { inflammation } \\
\text { C57BL/6J mice }\end{array}$ & $\begin{array}{l}\text { Drink water } \\
\text { with } 0.1 \% \text { VPP } \\
\text { for } 4 \text { months }\end{array}$ & $\begin{array}{l}\text { Reduce TNF- } \alpha \text { and } \\
\text { IL- } 1 \beta \text { expression } \\
\text { and macrophage } \\
\text { accumulation } \\
\text { and activation }\end{array}$ & $\begin{array}{c}\text { Attenuate } \\
\text { inflammation }\end{array}$ & {$[31]$} \\
\hline VPP, IPP & Milk casein & $\begin{array}{l}\text { Apolipoprotein } \\
\text { E-deficient } \\
\text { mice }\end{array}$ & $\begin{array}{c}\text { Oral } 60.2 \text { or } \\
125 \mu \mathrm{mol} / \mathrm{kg} \\
\text { BW/d peptide }\end{array}$ & $\begin{array}{l}\text { Reduce IL- } 6 \text {, IL-1 } \beta \text {, } \\
\text { and oxidized low- } \\
\text { density lipoprotein } \\
\text { receptor }\end{array}$ & $\begin{array}{c}\text { Attenuate } \\
\text { atherosclerosis }\end{array}$ & {$[71]$} \\
\hline VPP, IPP & Milk $\kappa$-casein & $\begin{array}{l}\text { L-NAME- } \\
\text { treated rats }\end{array}$ & $\begin{array}{c}\text { Drink water } \\
\text { with } 0.3 \mathrm{mg} / \mathrm{mL} \\
\text { VPP or IPP }\end{array}$ & $\begin{array}{c}\text { Increase } \\
\text { vasorelaxation and } \\
\text { nitrite and nitrate } \\
\text { and reduce cardiac } \\
\text { and renal damage }\end{array}$ & $\begin{array}{c}\text { Attenuate arterial } \\
\text { dysfunction }\end{array}$ & {$[72]$} \\
\hline VPY & $\begin{array}{l}\text { Soybean } \\
\text { protein }\end{array}$ & $\begin{array}{l}\text { DSS-induced } \\
\text { colitis BALB/C } \\
\text { female mice }\end{array}$ & $\begin{array}{c}\text { Drink water } \\
\text { with } 1 \mathrm{mg} / \mathrm{mL} \\
\mathrm{VPY} \\
(100 \mathrm{mg} / \mathrm{kg} \\
\mathrm{BW} / \mathrm{d})\end{array}$ & $\begin{array}{l}\text { Reduce DAI, weight } \\
\text { loss, and MPO } \\
\text { activity and } \\
\text { expressions of TNF- } \\
\alpha, \text { IL- } 6 \text {, IL- } 1 \beta, \text { IFN- } \gamma \text {, } \\
\text { and IL-17 }\end{array}$ & $\begin{array}{c}\text { Treat IBD via } \\
\text { PepT1 }\end{array}$ & {$[33]$} \\
\hline WH & $\begin{array}{l}\text { Sardine muscle } \\
\text { hydrolysate }\end{array}$ & $\begin{array}{l}\text { DSS-induced } \\
\text { colitis BALB/c } \\
\text { mice }\end{array}$ & $\begin{array}{c}\text { Oral } 100 \text { or } \\
250 \mathrm{mg} / \mathrm{kg} \\
\mathrm{BW} / \mathrm{d} \mathrm{WH} \text { for } \\
14 \mathrm{~d}\end{array}$ & $\begin{array}{c}\text { Reduce DAI, } \\
\text { cytokine expression, } \\
\text { MAPK and I } \kappa \mathrm{B} \alpha \\
\text { activation, and IL-8 } \\
\text { secretion }\end{array}$ & $\begin{array}{l}\text { Inhibit intestinal } \\
\text { inflammation }\end{array}$ & {$[41]$} \\
\hline Milk casein hydrolysates & $\begin{array}{l}\text { Lactobacillus } \\
\text { fermentation }\end{array}$ & $\begin{array}{l}\text { TNBS-induced } \\
\text { colitis mice }\end{array}$ & $\begin{array}{l}\text { Oral } 150 \mu \mathrm{g} / \mathrm{d} \\
\text { hydrolysate }\end{array}$ & $\begin{array}{l}\text { Reduce BW loss, } \\
\text { microbial } \\
\text { translocation, } \\
\text { colonic DAI, and } \\
\text { IFN- } \gamma \text { production }\end{array}$ & Treat colitis & {$[73]$} \\
\hline Di- and tripeptides & $\begin{array}{l}\text { Soybean } \\
\text { protein }\end{array}$ & $\begin{array}{l}\text { DSS-induced } \\
\text { colitis pig }\end{array}$ & $\begin{array}{c}\text { Infuse } \\
250 \mathrm{mg} / \mathrm{kg} \\
\text { BW/d peptides }\end{array}$ & $\begin{array}{l}\text { Reduce the } \\
\text { expressions of IFNG, } \\
\text { IL-1B, IL-12B, TNF, } \\
\text { and IL-17A and } \\
\text { MPO activity and } \\
\text { increase Foxp3 } \\
\text { expression and } \\
\text { CD } 4^{+} \mathrm{CD} 25^{+} \mathrm{T} \text { cells }\end{array}$ & $\begin{array}{l}\text { Attenuate colon } \\
\text { and ileum } \\
\text { inflammation }\end{array}$ & {$[74]$} \\
\hline Peptide P-317 & $\begin{array}{c}\text { Cyclic } \\
\text { analog of } \\
\text { morphiceptin }\end{array}$ & $\begin{array}{l}\text { TNBS/DSS- } \\
\text { induced colonic } \\
\text { mice }\end{array}$ & $\begin{array}{l}\text { Intraperitoneal } \\
0.2 \text { or oral } \\
2 \mathrm{mg} / \mathrm{kg} \mathrm{BW} / \mathrm{d} \\
\text { peptide }\end{array}$ & $\begin{array}{c}\text { Inhibit TNF- } \alpha \\
\text { and IL- } 1 \beta \text { expression } \\
\text { and MPO activity }\end{array}$ & Treat IBD & {$[75]$} \\
\hline pyroGlu-Leu & Wheat gluten & $\begin{array}{l}\text { DSS-induced } \\
\text { colitis mice }\end{array}$ & $\begin{array}{l}\text { Gavage } 0.01- \\
10 \mathrm{mg} / \mathrm{kg} \mathrm{BW} / \mathrm{d} \\
\text { peptide }\end{array}$ & $\begin{array}{c}\text { Reduce DAI and } \\
\text { normalize colonic } \\
\text { Bacteroidetes and } \\
\text { Firmicutes }\end{array}$ & $\begin{array}{c}\text { Treat IBD via gut } \\
\text { microbiota }\end{array}$ & {$[76]$} \\
\hline
\end{tabular}


TABLE 2: Continued.

\begin{tabular}{|c|c|c|c|c|c|c|}
\hline Peptides & Origin & Object & Administration & Activities & Results & Reference \\
\hline$\beta$-Casofensin & Milk protein & $\begin{array}{l}\text { NMS-induced } \\
\text { intestinal } \\
\text { barrier } \\
\text { alteration rat }\end{array}$ & $\begin{array}{l}\text { Oral } 10 \mu \mathrm{L} / \mathrm{kg} \\
\text { BW/d peptide } \\
(0.01-100 \mu \mathrm{M})\end{array}$ & $\begin{array}{c}\text { Reduce intestinal } \\
\text { damages and prevent } \\
\text { neonatal stress }\end{array}$ & Protect gut barrier & [77] \\
\hline$\gamma$-EC, $\gamma$-EV & $\begin{array}{c}\text { Beans and yeast } \\
\text { extracts }\end{array}$ & $\begin{array}{l}\text { DSS-induced } \\
\text { BALB/C female } \\
\text { mice }\end{array}$ & $\begin{array}{l}\text { Gavage } 50 \text { or } \\
150 \mathrm{mg} / \mathrm{kg} \\
\text { BW/d peptide }\end{array}$ & $\begin{array}{l}\text { Inhibit } \mathrm{I} \kappa \mathrm{B} \alpha \text { and JNK } \\
\text { activation and the } \\
\text { expressions of } \\
\text { TNF- } \alpha \text {, IL- } 6 \text {, INF- } \gamma \text {, } \\
\text { IL- } 1 \beta \text {, and IL-17 } \\
\text { and increase IL-10 } \\
\text { expression }\end{array}$ & $\begin{array}{l}\text { Inhibit colitis } \\
\text { inflammation via } \\
\text { the TNF- } \alpha \text { pathway }\end{array}$ & {$[47]$} \\
\hline
\end{tabular}

ACE: angiotensin-converting enzyme; AOM: azoxymethane; BW: body weight; $\mathrm{CD} 4^{+} / \mathrm{CD} 8^{+}$: splenic T lymphocyte subpopulations; DAI: disease activity index; DSS: dextran sulfate sodium; Foxp3: a transcription factor that drives treg phenotypic differentiation; glycomacropeptide: a 64-amino acid peptide in stomach casein hydrolysis; HFD: high-fat diet; IBD: inflammatory bowel diseases; iNOS: inducible oxide nitric synthase; IFN: interferon; IKK $\beta$ : inhibitory $\kappa$ B kinase- $\beta$; IL-1 $\beta$ : interleukin-1 $\beta$; KC: keratinocyte-derived chemokine; LPS: lipopolysaccharide; L-NAME: N(G)-nitro-L-arginine methyl ester hydrochloride; MCP-1: monocyte chemoattractant protein-1; MPO: myeloperoxidase; NF- $\kappa$ B: nuclear factor- $\kappa \mathrm{B}$; NMS: neonatal maternal separation; NO: nitric oxide; PPAR $\gamma$ : peroxisome proliferator-activated receptor gamma; RAW264.7: a mouse macrophage cell line; SAMP8: senescence-accelerated mice prone 8; TGF- $\beta$ : transforming growth factor $\beta$; TJ: tight junction; TLR4: toll-like receptor 4; Th1/2/17: T-helper-cell-associated cytokine 1/2/17; TNBS: 2,4,6-trinitrobenzene sulfonic acid.

(Anaerotruncus, Bacteroides, Enterobacteriaceae, Lactobacilli, and Parabacteroides) have changed [92]. In general, when defensins decline, the abundance of bacteria from Bacteroides and Firmicutes would be increased [93].

It was reported that BAPs can exert anti-inflammation via changing the gut microbiota in several studies $[62,63$, 76]. For example, oral administration of anti-inflammatory peptide pyroGlu-Leu derived from wheat gluten can normalize the population of Bacteroidetes and Firmicutes in the colon of colitis mice [76]. Shannon and Simpson indices represent species richness and species evenness, respectively. The Simpson index and the abundance of Coprococcus-1, Desulfovibrio, and Ruminococcaceae-UCG-014 were increased by tripeptides IRW and IQW. Additionally, IQW decreased the abundance of Bacteroides and increased Parabacteroides, while the levels of Anaerotruncus, Ruminiclostridium-9, and Oscillibacter were increased by IRW [63]. Firmicutes and Actinobacteria species were increased, and the proportions of Bacteroidetes and Proteobacteria species were decreased by oral administration of IRW and IQW; therefore, the colonic inflammation was inhibited via regulation of intestinal microorganisms [62]. In addition, dietary dipeptide GQ changed the gut microbiota beneficially through increasing alpha diversity, bacterial loading, abundance of anaerobes and fiber-degrading bacteria (Phylum Fibrobacteres), and short-chain fatty acids in the gut [94].

In conclusion, the gut microbiota is a promising mechanism for BAPs to inhibit intestinal inflammation. However, the information of the mechanism underlying the effects of BAPs on gut microbiota is still lacking, and it needs more studies to explore the interaction between antiinflammation of BAPs and gut microbiota in the future.

\section{Conclusions and Future Perspectives}

In this review, the mechanism and pathways of food proteinderived BAPs to exert anti-inflammatory bioactivities were highlighted, including pathways (NF- $\kappa \mathrm{B}, \mathrm{MAPK}$, and JAK-STAT), PepT1, inflammatory mediators, and gut microbiota. Moreover, various in vitro and in vivo studies of BAPs on inflammation were reviewed, finding that PepT1 and gut microbiota are promising targets for the inhibition of BAPs on intestinal inflammation; however, their roles still need more further studies to be verified in the future.

The discovery of novel BAP sequences and their corresponding action mechanisms as well as gut microbiota and PepT1 involved in the mediation can provide new opportunities for better targeting of intestinal inflammation. More in vivo data, including pharmacokinetics and proper dosage and time of administration of BAPs, are needed before their application to humans and animals. The role of dietary BAPs in inhibiting intestinal inflammation represents a novel direction in nutraceuticals for people or animals with intestinal inflammation.

\section{Conflicts of Interest}

The authors declare that they have no competing interests.

\section{Acknowledgments}

This work was supported by grants from the State Key Laboratory of Animal Nutrition (2004DA125184F1906) and the Fundamental Research Funds for the Central Universities (2662019QD021).

\section{References}

[1] K. Majumder, Y. Mine, and J. Wu, "The potential of food protein-derived anti-inflammatory peptides against various chronic inflammatory diseases," Journal of the Science of Food and Agriculture, vol. 96, no. 7, pp. 2303-2311, 2016. 
[2] S. Chakrabarti, F. Jahandideh, and J. Wu, "Food-derived bioactive peptides on inflammation and oxidative stress," BioMed Research International, vol. 2014, Article ID 608979, 11 pages, 2014.

[3] Q. Xu, H. Hong, J. Wu, and X. Yan, "Bioavailability of bioactive peptides derived from food proteins across the intestinal epithelial membrane: a review," Trends in Food Science and Technology, vol. 86, pp. 399-411, 2019.

[4] S. de Silva, S. Devlin, and R. Panaccione, "Optimizing the safety of biologic therapy for IBD," Nature Reviews. Gastroenterology \& Hepatology, vol. 7, no. 2, pp. 93-101, 2010.

[5] Z. F. Bhat, S. Kumar, and H. F. Bhat, "Antihypertensive peptides of animal origin: a review," Critical Reviews in Food Science and Nutrition, vol. 57, no. 3, pp. 566-578, 2017.

[6] Z. Jiehui, M. Liuliu, X. Haihong et al., "Immunomodulating effects of casein-derived peptides QEPVL and QEPV on lymphocytes in vitro and in vivo," Food \& Function, vol. 5, no. 9, pp. 2061-2069, 2014.

[7] S. Guha and K. Majumder, "Structural-features of foodderived bioactive peptides with anti-inflammatory activity: a brief review," Journal of Food Biochemistry, vol. 43, no. 1, article e12531, 2019.

[8] A. R. Jurjus, N. N. Khoury, and J.-M. Reimund, "Animal models of inflammatory bowel disease," Journal of Pharmacological and Toxicological Methods, vol. 50, no. 2, pp. 81-92, 2004.

[9] C.-C. Chu, Y.-C. Hou, M.-H. Pai, C.-J. Chao, and S.-L. Yeh, "Pretreatment with alanyl-glutamine suppresses T-helpercell-associated cytokine expression and reduces inflammatory responses in mice with acute DSS-induced colitis," The Journal of Nutritional Biochemistry, vol. 23, no. 9, pp. 1092-1099, 2012.

[10] H. Zhang, C. A. A. Hu, J. Kovacs-Nolan, and Y. Mine, "Bioactive dietary peptides and amino acids in inflammatory bowel disease," Amino Acids, vol. 47, no. 10, pp. 2127-2141, 2015.

[11] K. Majumder, S. Chakrabarti, J. S. Morton et al., "Egg-derived tri-peptide IRW exerts antihypertensive effects in spontaneously hypertensive rats," PLoS One, vol. 8, no. 11, article e82829, 2013.

[12] K. Majumder, S. Chakrabarti, S. T. Davidge, and J. Wu, "Structure and activity study of egg protein ovotransferrin derived peptides (IRW and IQW) on endothelial inflammatory response and oxidative stress," Journal of Agricultural and Food Chemistry, vol. 61, no. 9, pp. 2120-2129, 2013.

[13] G. Pepe, E. Sommella, G. Ventre et al., “Antioxidant peptides released from gastrointestinal digestion of "Stracchino" soft cheese: characterization, in vitro intestinal protection and bioavailability," Journal of Functional Foods, vol. 26, pp. 494-505, 2016.

[14] V. P. Dia, W. Wang, V. L. Oh, B. O. Lumen, and E. G. de Mejia, "Isolation, purification and characterisation of lunasin from defatted soybean flour and in vitro evaluation of its antiinflammatory activity," Food Chemistry, vol. 114, no. 1, pp. 108-115, 2009.

[15] X. Yang, J. Zhu, C.-Y. Tung et al., "Lunasin alleviates allergic airway inflammation while increases antigen-specific tregs," PLoS One, vol. 10, no. 2, article e0115330, 2015.

[16] Q. Xu, N. Singh, H. Hong et al., "Hen protein-derived peptides as the blockers of human bitter taste receptors T2R4, T2R7 and T2R14," Food Chemistry, vol. 283, pp. 621-627, 2019.
[17] X. Wang, Y. Zhao, Y. Yao et al., "Anti-inflammatory activity of di-peptides derived from ovotransferrin by simulated peptidecut in TNF- $\alpha$-induced Caco- 2 cells," Journal of Functional Foods, vol. 37, pp. 424-432, 2017.

[18] M. Zhang, Y. Zhao, Y. Yao et al., "Isolation and identification of peptides from simulated gastrointestinal digestion of preserved egg white and their anti-inflammatory activity in TNF- $\alpha$-induced Caco- 2 cells," The Journal of Nutritional Biochemistry, vol. 63, pp. 44-53, 2019.

[19] Y. Ma, J. Liu, H. Shi, and L. Yu, "Isolation and characterization of anti-inflammatory peptides derived from whey protein," Journal of Dairy Science, vol. 99, no. 9, pp. 6902-6912, 2016.

[20] S.-J. Kwak, C.-S. Kim, M.-S. Choi et al., "The soy peptide PheLeu-Val reduces TNF $\alpha$-induced inflammatory response and insulin resistance in adipocytes," Journal of Medicinal Food, vol. 19, no. 7, pp. 678-685, 2016.

[21] M. del Carmen Millán-Linares, F. Millán, J. Pedroche, and M. del Mar Yust, "GPETAFLR: a new anti-inflammatory peptide from Lupinus angustifolius L. protein hydrolysate," Journal of Functional Foods, vol. 18, pp. 358-367, 2015.

[22] A. Montoya-Rodríguez, E. G. de Mejía, V. P. Dia, C. ReyesMoreno, and J. Milán-Carrillo, "Extrusion improved the anti-inflammatory effect of amaranth (Amaranthus hypochondriacus) hydrolysates in LPS-induced human THP-1 macrophage-like and mouse RAW 264.7 macrophages by preventing activation of NF- $\kappa \mathrm{B}$ signaling," Molecular Nutrition \& Food Research, vol. 58, no. 5, pp. 1028-1041, 2014.

[23] M. Oyama, T. Van Hung, K. Yoda, F. He, and T. Suzuki, “A novel whey tetrapeptide IPAV reduces interleukin-8 production induced by TNF- $\alpha$ in human intestinal Caco- 2 cells," Journal of Functional Foods, vol. 35, pp. 376-383, 2017.

[24] W. Huang, S. Chakrabarti, K. Majumder, Y. Jiang, S. T. Davidge, and J. Wu, "Egg-derived peptide IRW inhibits TNF- $\alpha$-induced inflammatory response and oxidative stress in endothelial cells," Journal of Agricultural and Food Chemistry, vol. 58, no. 20, pp. 10840-10846, 2010.

[25] T.-S. Vo, B. Ryu, and S.-K. Kim, "Purification of novel antiinflammatory peptides from enzymatic hydrolysate of the edible microalgal Spirulina maxima," Journal of Functional Foods, vol. 5, no. 3, pp. 1336-1346, 2013.

[26] C. B. Ahn, Y. S. Cho, and J. Y. Je, "Purification and antiinflammatory action of tripeptide from salmon pectoral fin byproduct protein hydrolysate," Food Chemistry, vol. 168, pp. 151-156, 2015.

[27] M.-L. Cheng, H.-C. Wang, K.-C. Hsu, and J.-S. Hwang, “Antiinflammatory peptides from enzymatic hydrolysates of tuna cooking juice," Food and Agricultural Immunology, vol. 26, no. 6, pp. 770-781, 2015.

[28] S.-J. Lee, E.-K. Kim, Y.-S. Kim et al., "Purification and characterization of a nitric oxide inhibitory peptide from Ruditapes philippinarum," Food and Chemical Toxicology, vol. 50, no. 5, pp. 1660-1666, 2012.

[29] M. González-Montoya, B. Hernández-Ledesma, J. M. Silván, R. Mora-Escobedo, and C. Martínez-Villaluenga, "Peptides derived from in vitro gastrointestinal digestion of germinated soybean proteins inhibit human colon cancer cells proliferation and inflammation," Food Chemistry, vol. 242, pp. 75-82, 2018.

[30] J. Moronta, P. L. Smaldini, G. H. Docena, and M. C. Añón, "Peptides of amaranth were targeted as containing sequences with potential anti-inflammatory properties," Journal of Functional Foods, vol. 21, pp. 463-473, 2016. 
[31] Y. Sawada, Y. Sakamoto, M. Toh et al., "Milk-derived peptide Val-Pro-Pro (VPP) inhibits obesity-induced adipose inflammation via an angiotensin-converting enzyme (ACE) dependent cascade," Molecular Nutrition \& Food Research, vol. 59, no. 12 , pp. 2502-2510, 2015.

[32] S. Chakrabarti and J. Wu, "Milk-derived tripeptides IPP (IlePro-Pro) and VPP (Val-Pro-Pro) promote adipocyte differentiation and inhibit inflammation in 3T3-F442A cells," PLoS One, vol. 10, no. 2, article e0117492, 2015.

[33] J. Kovacs-Nolan, H. Zhang, M. Ibuki et al., "The PepT1transportable soy tripeptide VPY reduces intestinal inflammation," Biochimica et Biophysica Acta (BBA) - General Subjects, vol. 1820, no. 11, pp. 1753-1763, 2012.

[34] L. Zhao, X. Wang, X.-L. Zhang, and Q.-F. Xie, "Purification and identification of anti-inflammatory peptides derived from simulated gastrointestinal digests of velvet antler protein ( Cervus elaphus Linnaeus)," Journal of Food and Drug Analysis, vol. 24, no. 2, pp. 376-384, 2016.

[35] D. O. Son, H. Satsu, Y. Kiso, M. Totsuka, and M. Shimizu, "Inhibitory effect of carnosine on interleukin-8 production in intestinal epithelial cells through translational regulation," Cytokine, vol. 42, no. 2, pp. 265-276, 2008.

[36] S. Hirai, S. Horii, Y. Matsuzaki et al., "Anti-inflammatory effect of pyroglutamyl-leucine on lipopolysaccharidestimulated RAW 264.7 macrophages," Life Sciences, vol. 117, no. 1, pp. 1-6, 2014.

[37] S. Li, L. Liu, G. He, and J. Wu, "Molecular targets and mechanisms of bioactive peptides against metabolic syndromes," Food \& Function, vol. 9, no. 1, pp. 42-52, 2018.

[38] S. Li, T. Bu, J. Zheng, L. Liu, G. He, and J. Wu, "Preparation, bioavailability, and mechanism of emerging activities of IlePro-Pro and Val-Pro-Pro," Comprehensive Reviews in Food Science and Food Safety, vol. 18, no. 4, pp. 1097-1110, 2019.

[39] T. Zhang, J. McCarthy, G. Wang, Y. Liu, and M. Guo, "Physiochemical properties, microstructure, and probiotic survivability of nonfat goats' milk yogurt using heat-treated whey protein concentrate as fat replacer," Journal of Food Science, vol. 80, no. 4, pp. M788-M794, 2015.

[40] M. Tanaka, S. M. Hong, S. Akiyama, Q. Q. Hu, and T. Matsui, "Visualized absorption of anti-atherosclerotic dipeptide, TrpHis, in Sprague-Dawley rats by LC-MS and MALDI-MS imaging analyses," Molecular Nutrition \& Food Research, vol. 59, no. 8, pp. 1541-1549, 2015.

[41] Y. Kobayashi, J. Kovacs-Nolan, T. Matsui, and Y. Mine, “The anti-atherosclerotic dipeptide, Trp-His, reduces intestinal inflammation through the blockade of L-type $\mathrm{Ca}^{2+}$ channels," Journal of Agricultural and Food Chemistry, vol. 63, no. 26, pp. 6041-6050, 2015.

[42] P. P. Tak and G. S. Firestein, "NF- $\kappa$ B: a key role in inflammatory diseases," The Journal of Clinical Investigation, vol. 107, no. 1, pp. 7-11, 2001.

[43] T.-Y. Ho, C.-C. Li, H.-Y. Lo, F.-Y. Chen, and C.-Y. Hsiang, "Corn silk extract and its bioactive peptide ameliorated lipopolysaccharide-induced inflammation in mice via the nuclear factor- $\kappa \mathrm{B}$ signaling pathway," Journal of Agricultural and Food Chemistry, vol. 65, no. 4, pp. 759-768, 2017.

[44] P. K. Roy, F. Rashid, J. Bragg et al., "Role of the JNK signal transduction pathway in inflammatory bowel disease," World Journal of Gastroenterology, vol. 14, no. 2, pp. 200-202, 2008.

[45] S. Dumeus, M. A. Shibu, W.-T. Lin et al., "Bioactive peptide improves diet-induced hepatic fat deposition and hepatocyte proinflammatory response in SAMP8 ageing mice," Cellular Physiology and Biochemistry, vol. 48, no. 5, pp. 1942-1952, 2018.

[46] K. Aihara, M. Osaka, and M. Yoshida, "Oral administration of the milk casein-derived tripeptide Val-Pro-Pro attenuates high-fat diet-induced adipose tissue inflammation in mice," The British Journal of Nutrition, vol. 112, no. 4, pp. 513-519, 2014.

[47] H. Zhang, J. Kovacs-Nolan, T. Kodera, Y. Eto, and Y. Mine, “ $\gamma$ Glutamyl cysteine and $\gamma$-glutamyl valine inhibit TNF- $\alpha$ signaling in intestinal epithelial cells and reduce inflammation in a mouse model of colitis via allosteric activation of the calcium-sensing receptor," Biochimica et Biophysica Acta (BBA) - Molecular Basis of Disease, vol. 1852, no. 5, pp. 792804, 2015.

[48] M. Chalamaiah, W. Yu, and J. Wu, "Immunomodulatory and anticancer protein hydrolysates (peptides) from food proteins: a review," Food Chemistry, vol. 245, pp. 205-222, 2018.

[49] D. E. W. Chatterton, D. N. Nguyen, S. B. Bering, and P. T. Sangild, "Anti-inflammatory mechanisms of bioactive milk proteins in the intestine of newborns," The International Journal of Biochemistry \& Cell Biology, vol. 45, no. 8, pp. 17301747, 2013.

[50] K. Aihara, H. Ishii, and M. Yoshida, "Casein-derived tripeptide, Val-Pro-Pro (VPP), modulates monocyte adhesion to vascular endothelium," Journal of Atherosclerosis and Thrombosis, vol. 16, no. 5, pp. 594-603, 2009.

[51] E. Maestri, M. Marmiroli, and N. Marmiroli, "Bioactive peptides in plant-derived foodstuffs," Journal of Proteomics, vol. 147, pp. 140-155, 2016.

[52] Y. Zhou, P. Zhang, G. Deng, X. Liu, and D. Lu, "Improvements of immune status, intestinal integrity and gain performance in the early-weaned calves parenterally supplemented with 1-alanyl-l-glutamine dipeptide," Veterinary Immunology and Immunopathology, vol. 145, no. 1-2, pp. 134-142, 2012.

[53] Y.-C. Hou, C.-C. Chu, T.-L. Ko, C.-L. Yeh, and S.-L. Yeh, "Effects of alanyl-glutamine dipeptide on the expression of colon-inflammatory mediators during the recovery phase of colitis induced by dextran sulfate sodium," European Journal of Nutrition, vol. 52, no. 3, pp. 1089-1098, 2013.

[54] Y.-C. Hou, J.-J. Liu, M.-H. Pai, S.-S. Tsou, and S.-L. Yeh, “Alanyl-glutamine administration suppresses Th17 and reduces inflammatory reaction in dextran sulfate sodium-induced acute colitis," International Immunopharmacology, vol. 17, no. 1, pp. 1-8, 2013.

[55] M. Lee, J. Kovacs-Nolan, T. Archbold et al., "Therapeutic potential of hen egg white peptides for the treatment of intestinal inflammation," Journal of Functional Foods, vol. 1, no. 2, pp. 161-169, 2009.

[56] D. A. Luna-Vital, E. González de Mejía, and G. Loarca-Piña, "Dietary peptides from phaseolus vulgaris L. reduced AOM/DSS-induced colitis-associated colon carcinogenesis in Balb/c mice," Plant Foods for Human Nutrition, vol. 72, no. 4, pp. 445-447, 2017.

[57] P. Requena, A. Daddaoua, E. Martínez-Plata et al., "Bovine glycomacropeptide ameliorates experimental rat ileitis by mechanisms involving downregulation of interleukin 17," British Journal of Pharmacology, vol. 154, no. 4, pp. 825-832, 2008.

[58] R. López-Posadas, P. Requena, R. González et al., "Bovine glycomacropeptide has intestinal antiinflammatory effects in rats 
with dextran sulfate-induced colitis," The Journal of Nutrition, vol. 140, no. 11, pp. 2014-2019, 2010.

[59] M. Ortega-González, F. Capitán-Cañadas, P. Requena et al., "Validation of bovine glycomacropeptide as an intestinal anti-inflammatory nutraceutical in the lymphocyte-transfer model of colitis," The British Journal of Nutrition, vol. 111, no. 7, pp. 1202-1212, 2014.

[60] Z. Ming, Y. Jia, Y. Yan, G. Pang, and Q. Chen, “Amelioration effect of bovine casein glycomacropeptide on ulcerative colitis in mice," Food and Agricultural Immunology, vol. 26, no. 5, pp. 717-728, 2015.

[61] H. Jiao, Q. Zhang, Y. Lin, Y. Gao, and P. Zhang, "The ovotransferrin-derived peptide IRW attenuates lipopolysaccharide-induced inflammatory responses," BioMed Research International, vol. 2019, Article ID 8676410, 7 pages, 2019.

[62] Y. Ma, S. Ding, G. Liu et al., "Egg protein transferrin-derived peptides IRW and IQW regulate citrobacter rodentiuminduced, inflammation-related microbial and metabolomic profiles," Frontiers in Microbiology, vol. 10, p. 643, 2019.

[63] G. Liu, W. Yan, S. Ding et al., "Effects of IRW and IQW on oxidative stress and gut microbiota in dextran sodium sulfateinduced colitis," Cellular Physiology and Biochemistry, vol. 51, no. 1, pp. 441-451, 2018.

[64] Y. Ma, H. Jiang, J. Fang, and G. Liu, "IRW and IQW reduce colitis-associated cancer risk by alleviating DSS-induced colonic inflammation," BioMed Research International, vol. 2019, Article ID 6429845, 9 pages, 2019.

[65] E. Shapira, B. Brodsky, E. Proscura, A. Nyska, A. ErlangerRosengarten, and U. Wormser, "Amelioration of experimental autoimmune encephalitis by novel peptides: involvement of T regulatory cells," Journal of Autoimmunity, vol. 35, no. 1, pp. 98-106, 2010.

[66] G. Dalmasso, L. Charrier-Hisamuddin, H. T. Thu Nguyen, Y. Yan, S. Sitaraman, and D. Merlin, "PepT1-mediated tripeptide KPV uptake reduces intestinal inflammation," Gastroenterology, vol. 134, no. 1, pp. 166-178, 2008.

[67] H. Hou, Y. Fan, S. Wang, L. Si, and B. Li, "Immunomodulatory activity of Alaska pollock hydrolysates obtained by glutamic acid biosensor - artificial neural network and the identification of its active central fragment," Journal of Functional Foods, vol. 24, pp. 37-47, 2016.

[68] J.-W. Hwang, S.-J. Lee, Y.-S. Kim et al., "Purification and characterization of a novel peptide with inhibitory effects on colitis induced mice by dextran sulfate sodium from enzymatic hydrolysates of Crassostrea gigas," Fish \& Shellfish Immunology, vol. 33, no. 4, pp. 993-999, 2012.

[69] N. Eissa, H. Hussein, L. Kermarrec et al., "Chromofungin ameliorates the progression of colitis by regulating alternatively activated macrophages," Frontiers in Immunology, vol. 8, p. 1131, 2017.

[70] J. Moronta, P. L. Smaldini, C. A. Fossati, M. C. Añon, and G. H. Docena, "The anti-inflammatory SSEDIKE peptide from Amaranth seeds modulates IgE-mediated food allergy," Journal of Functional Foods, vol. 25, pp. 579-587, 2016.

[71] T. Nakamura, T. Hirota, K. Mizushima et al., "Milk-derived peptides, Val-Pro-Pro and Ile-Pro-Pro, attenuate atherosclerosis development in apolipoprotein E-deficient mice: a preliminary study," Journal of Medicinal Food, vol. 16, no. 5, pp. 396-403, 2013.
[72] A. Nonaka, T. Nakamura, T. Hirota et al., "The milk-derived peptides Val-Pro-Pro and Ile-Pro-Pro attenuate arterial dysfunction in L-NAME-treated rats," Hypertension Research, vol. 37, no. 8, pp. 703-707, 2014.

[73] M. B. Espeche Turbay, A. de Moreno de LeBlanc, G. Perdigón, G. Savoy de Giori, and E. M. Hebert, " $\beta$-Casein hydrolysate generated by the cell envelope-associated proteinase of Lactobacillus delbrueckii ssp. lactis CRL 581 protects against trinitrobenzene sulfonic acid-induced colitis in mice," Journal of Dairy Science, vol. 95, no. 3, pp. 1108-1118, 2012.

[74] D. Young, M. Ibuki, T. Nakamori, M. Fan, and Y. Mine, "Soyderived di- and tripeptides alleviate colon and ileum inflammation in pigs with dextran sodium sulfate-induced colitis," The Journal of Nutrition, vol. 142, no. 2, pp. 363-368, 2012.

[75] M. Sobczak, P. K. Zakrzewski, A. I. Cygankiewicz et al., “Antiinflammatory action of a novel orally available peptide 317 in mouse models of inflammatory bowel diseases," Pharmacological Reports, vol. 66, no. 5, pp. 741-750, 2014.

[76] S. Wada, K. Sato, R. Ohta et al., "Ingestion of low dose pyroglutamyl leucine improves dextran sulfate sodium-induced colitis and intestinal microbiota in mice," Journal of Agricultural and Food Chemistry, vol. 61, no. 37, pp. 8807-8813, 2013.

[77] C. Bessette, G. Henry, S. Sekkal et al., "Oral administration of a casein matrix containing $\beta$-casofensin protects the intestinal barrier in two preclinical models of gut diseases," Journal of Functional Foods, vol. 27, pp. 223-235, 2016.

[78] S. La Manna, C. Di Natale, D. Florio, and D. Marasco, "Peptides as therapeutic agents for inflammatory-related diseases," International Journal of Molecular Sciences, vol. 19, no. 9, p. 2714, 2018.

[79] O. Martínez-Augustin, B. Rivero-Gutiérrez, C. Mascaraque, and F. Sánchez de Medina, "Food derived bioactive peptides and intestinal barrier function," International Journal of Molecular Sciences, vol. 15, no. 12, pp. 22857-22873, 2014.

[80] Q. B. Xu, Y. D. Zhang, N. Zheng et al., "Short communication: decrease of lipid profiles in cow milk by ultra-hightemperature treatment but not by pasteurization," Journal of Dairy Science, vol. 103, no. 2, pp. 1900-1907, 2020.

[81] Q. Xu, X. Yan, Y. Zhang, and J. Wu, "Current understanding of transport and bioavailability of bioactive peptides derived from dairy proteins: a review," International Journal of Food Science and Technology, vol. 54, no. 6, pp. 1930-1941, 2019.

[82] L. Santiago-Lopez, A. F. Gonzalez-Cordova, A. HernandezMendoza, and B. Vallejo-Cordoba, "Potential use of food protein-derived peptides in the treatment of inflammatory diseases," Protein \& Peptide Letters, vol. 24, no. 2, pp. 137-145, 2017.

[83] Q. Xu, Z. Liu, H. Liu et al., "Functional characterization of oligopeptide transporter 1 of dairy cows," Journal of Animal Science and Biotechnology, vol. 9, no. 1, p. 7, 2018.

[84] Q. Xu, Y. Wu, H. Liu, Y. Xie, X. Huang, and J. Liu, "Establishment and characterization of an omasal epithelial cell model derived from dairy calves for the study of small peptide absorption," PLoS One, vol. 9, no. 3, article e88993, 2014.

[85] Q. Xu, H. Liu, F. Zhao et al., "Mechanism of peptide absorption in the isolated forestomach epithelial cells of dairy cows," Journal of the Science of Food and Agriculture, vol. 99, no. 1, pp. 100-108, 2018.

[86] S. A. Ingersoll, S. Ayyadurai, M. A. Charania, H. Laroui, Y. Yan, and D. Merlin, "The role and pathophysiological relevance of membrane transporter PepT1 in intestinal 
inflammation and inflammatory bowel disease," American Journal of Physiology-Gastrointestinal and Liver Physiology, vol. 302, no. 5, pp. G484-G492, 2012.

[87] L. Charrier and D. Merlin, "The oligopeptide transporter hPepT1: gateway to the innate immune response," Laboratory Investigation, vol. 86, no. 6, pp. 538-546, 2006.

[88] Q. Xu, H. Fan, W. Yu, H. Hong, and J. Wu, "Transport study of egg-derived antihypertensive peptides (LKP and IQW) using Caco-2 and HT29 coculture monolayers," Journal of Agricultural and Food Chemistry, vol. 65, no. 34, pp. 7406-7414, 2017.

[89] Q. Lin, Q. Xu, J. Bai, W. Wu, H. Hong, and J. Wu, “Transport of soybean protein-derived antihypertensive peptide LSW across Caco-2 monolayers," Journal of Functional Foods, vol. 39, pp. 96-102, 2017.

[90] H. Fan, Q. Xu, H. Hong, and J. Wu, "Stability and transport of spent hen-derived ACE-inhibitory peptides IWHHT, IWH, and IW in human intestinal Caco-2 cell monolayers," Journal of Agricultural and Food Chemistry, vol. 66, no. 43, pp. 1134711354, 2018.

[91] N. A. Nagalingam and S. V. Lynch, "Role of the microbiota in inflammatory bowel diseases," Inflammatory Bowel Diseases, vol. 18, no. 5, pp. 968-984, 2012.

[92] Å. Håkansson, N. Tormo-Badia, A. Baridi et al., "Immunological alteration and changes of gut microbiota after dextran sulfate sodium (DSS) administration in mice," Clinical and Experimental Medicine, vol. 15, no. 1, pp. 107-120, 2015.

[93] N. H. Salzman, K. Hung, D. Haribhai et al., "Enteric defensins are essential regulators of intestinal microbial ecology," Nature Immunology, vol. 11, no. 1, pp. 76-82, 2010.

[94] Y. Yan, B. Xu, B. Yin et al., "Modulation of gut microbial community and metabolism by dietary glycyl-glutamine supplementation may favor weaning transition in piglets," Frontiers in Microbiology, vol. 10, p. 3125, 2020. 